\title{
New Book Explores Academic Librarian Labour Activism in Canada
}

In Solidarity: Academic Librarian Labour Activism and Union Participation in Canada, a new book co-edited by Jennifer Dekker of the University of Ottawa and Mary Kandiuk, York University librarian and former Partnership Innovations in Practice editor, was published by Library Juice Press in October, 2014.

The collection documents the birth of labour organizing of academic librarians in Canada, explores some of the major labour issues affecting academic librarians in a certified and non-certified union context, and includes case studies relating to the unionization of academic librarians at selected institutions. Topics addressed include the history of academic librarian labour organizing, academic status, leadership in academic staff associations, collective bargaining, and recent attacks on

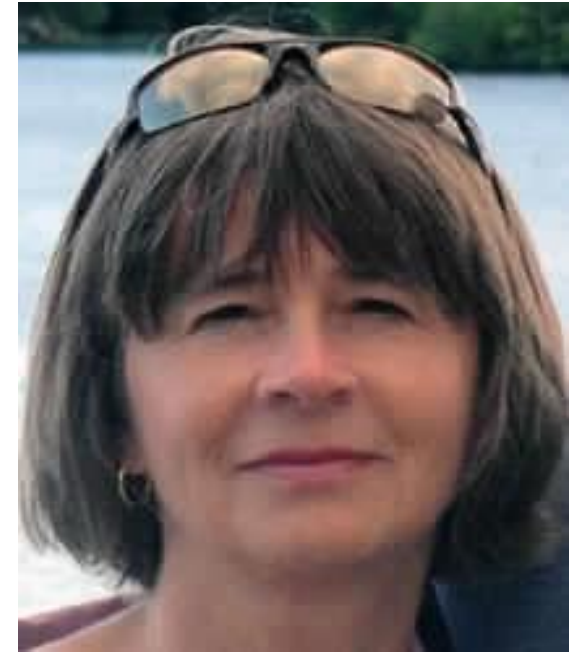

Mary Kandiuk the rights and occupational interests of academic librarians at Canadian universities. The volume includes a broad representation of academic librarian labour activists from across Canada. Little in the way of documentation exists on academic librarian union

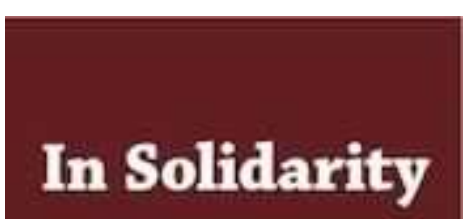
activism and participation in Canada, and this work contributes to original research in this area.

Readers will no doubt note that most of the contributions are written by female authors. Importantly, In Solidarity documents the struggles of a largely female occupational group to gain control of their working conditions. This is not surprising given that, as pointed out by Western University Professor Emerita Roma Harris in her seminal work Librarianship: The Erosion of a Woman's Profession, the "marginalization of librarianship" is due to the fact that it is a "woman's profession" and that the "undervaluing of library work" is a "product of its gendered nature." Librarians mostly female - mobilized early on to tackle issues of pay equity, academic status and professional autonomy. Frustrated by a lack of progress, they turned away from their professional associations and local library administrators and instead looked to the national academic labour organization, the Canadian Association of University Teachers (CAUT), as well as their local faculty associations, to further their collective professional interests.

Kandiuk, a recipient of the CAUT Academic Librarians' Distinguished Service Award, has been actively involved in the York University Faculty Association for many years, 
serving three terms as vice-president internal and as a member of three collective bargaining teams. Her own chapter in In Solidarity, "Academic Librarians at the Table Bargaining for Parity," examines how collective bargaining has long been used by academic librarians in Canada as a means of improving terms and conditions of employment and also in their pursuit of parity with faculty. It explores the structures and practices that are in place to support collective bargaining for academic librarians who are members of certified unions, the issues and challenges faced by academic librarians relating to collective bargaining and as members of faculty bargaining teams, and the strategies that have proven successful at the negotiating table. 